\section{Nitric Oxide Reduction in Methyl Nitrite Pyrolysis and the Transition from Isothermal Decomposition to Adiabatic Flame}

WHEN the lower alkyl nitrite and nitrate esters ${ }^{1,2}$ ( $R \mathrm{ONO}$ and $R \mathrm{ONO}_{2}$ ) decompose isothermally, they do so by initial fission of the $\mathrm{O}-\mathrm{N}$ bond yielding an alkoxyl radical $R \mathrm{O}$. and the appropriate oxide of nitrogen. This step commonly controls the rate of isothermal decomposition; the subsequent reactions of the initial products ${ }^{2}$ determine the stoichiometry. It has generally been assumed that the greater extent of decomposition of nitrates reflects the superior reactivity of nitrogen dioxide, while in the nitrites ${ }^{1}$ isothermal decomposition scarcely involves nitric oxide at all :

$\mathrm{CH}_{3} \mathrm{ONO}(\mathrm{g}) \rightarrow \mathrm{NO}(\mathrm{g})+0.5 \mathrm{CH}_{3} \mathrm{OH}(\mathrm{g})+0.5 \mathrm{CH}_{2} \mathrm{O}(\mathrm{g})$

$\Delta H$ c. zero

Views on the inertness of nitric oxide in the methyl nitrite system, first challenged by Carter and Travers ${ }^{3}$, had to be further revised when the methyl nitrite self-decomposition flame was discovered ${ }^{4}$ in 1955 ; this flame depends on nitric oxide reduction for its existence.

Two questions arise: (1) How are the adiabatic flame and the isothermal decomposition related?, and (2) How is the transition from decomposition to exothermic flame accomplished ?, for if normal decomposition does not proceed beyond nitric oxide and is genuinely thermoneutral, this transition can be induced only by external agencies. The investigation of these questions has thrown new light on the true course of isothermal decomposition.

The adiabatic flame. It has been found that the overall stoichiometry of the decomposition flame lies between the extremes predicted ${ }^{4}$. The products are basically the same as those reported earlier ${ }^{5,6}$ and reaction may be written :

$\mathrm{CH}_{3} \mathrm{ONO} \rightarrow 0.72 \mathrm{CO}+0.56 \mathrm{H}_{2}+0.54 \mathrm{NO}+0.42 \mathrm{H}_{2} \mathrm{O}$ $+0 \cdot 14 \mathrm{~N}_{2}+0.13 \mathrm{CH}_{3} \mathrm{OH}+0.10 \mathrm{CH}_{2} \mathrm{O}+0.06$ $\mathrm{NH}_{3}+0.05 \mathrm{~N}_{2} \mathrm{O}+0.02$ ' $\mathrm{CH}_{2} \mathrm{NOH}^{\prime}+0.02 \mathrm{CH}_{4}+$ $0.01 \mathrm{CO}_{2}$

The overall change in enthalpy thus resulting in the flame is $-27.0 \mathrm{kcal} . \mathrm{mole}^{-1}$ and this corresponds to a theoretical adiabatic flame temperature of $1,110^{\circ} \mathrm{C}$., which agrees very closely with the experimental ${ }^{5,7}$ value of $1,100^{\circ} \mathrm{C}$.

Thermal decomposition and flame. Thermal decomposition of the pure vapour at I atm. was first studied in a flow system to simulate conditions of the stationary methyl nitrite flame. Even at $250^{\circ} \mathrm{C}$., nitric oxide is reduced and water is formed. Reaction is correspondingly exothermic and thermocouple measurements show a $50 \mathrm{deg}$. rise in temperature. Thus a path is open by which methyl nitrite pyrolysis may become self-supporting; its potentialities are enhanced by the flexibility of a complex reaction mechanism ; as the temperature rises so the stoichiometry alters and more heat is released. Equation 3 adequately represents the decomposition products up to about $500^{\circ} \mathrm{C}$. where the self-heating is even more marked.

$\mathrm{CH}_{3} \mathrm{ONO} \rightarrow 0.76 \mathrm{NO}+0.46 \quad \mathrm{CH}_{2} \mathrm{O}+0.24 \quad \mathrm{CH}_{3} \mathrm{OH}+$ $0.19 \mathrm{H}_{2} \mathrm{O}+0 \cdot 12 \mathrm{~N}_{2} \mathrm{O}+$ some polymeric product $\Delta H=c .-7$ kcal.mole ${ }^{-1}$.

In the neighbourhood of $590^{\circ} \mathrm{C}$. the change in stoichiometry is particularly rapid, and thereafter differs very little from that of the flame. By $700^{\circ} \mathrm{C}$, a degree of self-heating of nearly $300^{\circ} \mathrm{C}$. is achieved; equation, 4 summarizes the course of reaction :

$\mathrm{CH}_{3} \mathrm{ONO} \rightarrow 0.536 \mathrm{NO}+0.10 \mathrm{CH}_{2} \mathrm{O}+0.11 \mathrm{CH}_{3} \mathrm{OH}+$
$0.42 \mathrm{H}_{2} \mathrm{O}+0.75 \mathrm{CO}+0.04 \mathrm{~N}_{2} \mathrm{O}+0.151 \mathrm{~N}_{2}+$
$0.06 \mathrm{NH}_{3}+0.01 \mathrm{CO}_{2}+0.01 \mathrm{CH}_{4}+0.02{ }^{\prime} \mathrm{CH}_{2} \mathrm{NOH}^{\prime}$

$\Delta H=c$. $-26 \mathrm{kcal}$.mole ${ }^{-1}$.

Isothermal decomposition. To establish whether the nitric oxide reduction discovered previously is merely $a_{4}$ consequence of self-heating, the low-temperature pyrolysis of methyl nitrite has been examined under conditions of constant temperature.

Decompositions were carried out in aged 'Pyrex' reaction vessels using static systems $\left(178-310^{\circ} \mathrm{C}\right.$.) and flow systems $\left(235-315^{\circ} \mathrm{C}\right.$.). Velocity constants and the mean activation energy $\left(36,400\right.$ cal.mole $\left.{ }^{-1}\right)$ agree with old measurements ${ }^{1}$. Nitrous oxide is always formed, the yield never dropping far from 0.13 mole $\mathrm{N}_{2} \mathrm{O}$ per mole nitrite decomposed. This figure is independent of temperature (from 235 to $315^{\circ}$ ), of reactant partial pressure (from 10 to $60 \mathrm{~mm}$. mercury), and of percentage decomposition (from $7 \cdot 7$ to 100). Thus, nitrous oxide is a normal product of $i$ sothermal methyl nitrite decomposition :

$$
\begin{array}{r}
\mathrm{CH}_{3} \mathrm{ONO} \rightarrow 0.74 \mathrm{NO}+0.13 \mathrm{~N}_{2} \mathrm{O}+0.66 \mathrm{CH}_{2} \mathrm{O}+0.30 \\
\mathrm{CH}_{3} \mathrm{OH}+0.12 \mathrm{H}_{2} \mathrm{O}
\end{array}
$$

The mechanism of nitrous oxide formation proposed by Levy $^{8}$ in work on ethyl nitrite seems attractive here. Nitric oxide abstracts hydrogen from free methoxyl and the nitroxyl formed is the source of nitrous oxide. Added nitric oxide (molecular ratio $\mathrm{NO}: \mathrm{CH}_{3} \mathrm{ONO}$ is $12: 1$ ) doubles the nitrous oxide yield without sensibly affecting the rate of reaction :

$$
\begin{aligned}
\mathrm{CH}_{3} \mathrm{ONO} & \rightarrow \mathrm{CH}_{3} \mathrm{O} \cdot+\mathrm{NO} ; \\
\mathrm{CH}_{3} \mathrm{O}+\mathrm{NO} & \rightarrow \mathrm{CH}_{2} \mathrm{O}+\mathrm{HNO} ; \\
2 \mathrm{HNO} & \rightarrow \mathrm{H}_{2} \mathrm{O}+\mathrm{N}_{2} \mathrm{O}
\end{aligned}
$$

At low temperatures, nitrogen is never found. It arises only at elevated temperatures, where it may be a product of secondary reactions undergone by nitrous oxide.

\section{Peter Gray}

School of Chemistry, A. Willitams

University of Leeds.

"Steacie, E. W. R., "Atomic and Free Radical Reactions" (Reinhold Publishing Corporation, New York, 1954).

${ }^{2}$ Gray, P., and Williams, A., Chem. Rev., 59, 239 (1959).

${ }^{3}$ Carter, A. G., and Travers, M. W., Proc. Roy. Soc., A, 158, 495 (1937). - Gray, P., Hall, A. R., and Wolfhard, H. G., Nature, 176, 695 (1955). - Gray, P., and Pratt, M. W. T., Sixth Symposium on Combustion (Reinhold Publishing Corporation, New York, 1957).

- Arden, E. A., and Powling, J., Combustion and Flame, 2, 55 (1958). ' Williams, A., Ph.D. dissertation, University of Leeds (1959). ${ }^{8}$ Levy, J. B., J. Amer. Chem. Soc., 78, 1780 (1956).

\section{Esterification of Fatty Acids with Glycerol}

SINCE Berthelot's classical work on the esterification of fatty acids with glycerol, in the last century, considerable work has been done on the topic ${ }^{1-4}$. The presence of 2-monoglyceride in technical products of glycerolysis has been reported recently ${ }^{5}$; this was not noticed by Feuge et al..$^{4}$ or by Becker et al. ${ }^{6}$ on the ground that 2-monoglyceride is prone to be quickly isomerized to the more stable 1-monoglyceride at the high temperature of the reaction. The present 